\title{
Solid Rabbit Fertilizer Development on Growth and Results Some Varieties of Chili (Capsicum Frutescens L.)
}

\author{
Anak Agung Ngurah Mayun Wirajaya ${ }^{1}$, Made Sri Yuliartini ${ }^{2}$, I Gusti Bagus Udayana ${ }^{3}$ \\ mawir61@yahoo.com ${ }^{1}$, yuliartinisri@yahoo.co.id ${ }^{2}$, bgsudayana64@gmail.com ${ }^{3}$ \\ Agrotechnology Study Program, Faculty of Agriculture-Warmadewa
University
}

\begin{abstract}
The purpose of this study was to obtain the most appropriate dense rabbit fertilizer for increasing fertility and the availability of nutrients and varieties that most respond to fertilization to get the best growth and yield of chilli. This research is a factorial experiment, with a randomized block design (RCBD) basic design with 2 factors tried and carried out in a greenhouse from April to September 2018. In the first factor the dose of rabbit manure from 4 levels: $\mathrm{K} 0=$ without fertilizer, $\mathrm{K} 1=10$ tons ha-1, K $2=20$ tons ha-1, K $3=30$ tons ha-1. The second factor with 3 levels: V 1 = Rawita variety, V 2 = Dewata variety, V 3 = Sigantung variety. From the experiment, 12 combination treatments will be repeated and will be repeated 3 times. The interaction $(\mathrm{K} \mathrm{x} \mathrm{V})$ between the development of solid rabbit manure $(\mathrm{K})$ on the growth and yield of some chilli varieties (V) (Capsicum frutescens L.) on all influential variables was not significant $(\mathrm{P} \geq 0.05)$. The fruit weight per plant in the highest solid rabbit fertilizer at K 3 was $107.10 \mathrm{~g}$ which was not significant with $\mathrm{K} 2$ and $\mathrm{K} 1$ at 95.48 $\mathrm{g}$ and $80.22 \mathrm{~g}$ which increased $12.17 \%$ and $33.51 \%$ and were significantly different with $\mathrm{K} 0$ which is $67.87 \mathrm{~g}$ where $\mathrm{K} 3$ increases by $57.80 \%$. The results of this study showed that the high fruit weight at dense rabbit fertilizer at K3 dose of 30 tons ha-1 supported by the highest plant height was obtained at K3 of $150.74 \mathrm{~cm}$, the highest number of branches was 9.11, the highest number of leaves was 321, 11 strands, the widest leaf area of $23,003.12 \mathrm{~cm} 2$, the highest number of fruits of 108.11 fruit, the heaviest leaf wet weight of $112.02 \mathrm{~g}$, the heaviest wet weight of stem and branch of $224.12 \mathrm{~g}$, the heaviest root wet weight of $107.12 \mathrm{~g}$. Fruit weight in the treatment of several varieties showed the highest response was obtained at V 2 (Rawita) which was $129.27 \mathrm{~g}$ significantly different from V 3 (Sigantung) and V1 (Dewata) which was $73.28 \mathrm{~g}$ and $60.46 \mathrm{~g}$ respectively increased by $76,41 \%$ and $113.81 \%$. The highest fruit weight in V2 is supported by the highest number of branches of 10.92 pieces, the highest number of leaves is 448.17 pieces, the highest number of fruits is 176.50 pieces.
\end{abstract}

Keywords: Dosage of Solid Rabbit Cage Fertilizer, Chili Varieties 


\section{Introduction}

Chili is a horticultural commodity that is still needed by the market. Availability in the market has many influencing factors including low production levels, environmental conditions in production centers and natural disasters, increasing community needs.

The high demand for chili in the community where its availability in the market cannot meet the demand, both for large chili (Capsicum annuum L.) and small chilli (Capsicum frutescens L.) makes it an opportunity and to meet demand and fill these opportunities through increased application cultivation technology in plants.

Giving manure to the planting media can provide an increase in nutrient supply which is one of the application of correct cultivation techniques. The number of types of manure that exist in the market causes the provision of chili plants to be tested where manure provides the greatest impact on plant growth and development. Mayun Wirajaya's research results; Yuliartini; Kartini [1] in testing several types of manure and pruning obtained the highest fresh fruit weight on the interaction of rabbit manure with apical trimming 16 days after planting (K3P2) of $47.67 \mathrm{~g}$ and when compared with the results of the combination without fertilizer and without trimming (K0P0) of $37.80 \mathrm{~g}$ there was an increase of $26.11 \%$. From the results of this study rabbit solid fertilizer gave the highest value, but it should be sought at which dose is most appropriate when given to chili plants. Provision of dense rabbit fertilizer with the right dose must be effective and effective.

Rabbit-dense fertilizers which have high nutrient content compared to other manure, may not be responded well to any chilli plant varieties. Adaptability, plant morphology and other abilities possessed by each variety will have different effects on plant growth and yield.

From the background explanation above the problem can be formulated is how many doses of rabbit solid fertilizer are right and the most responsive varieties are to get the best growth and yield of chili.

\section{Methodology}

\subsection{Place and time of research}

This study is an experiment in a greenhouse located at the Faculty of Agriculture, University Warmadewa Road Terompong No. 24 Cape bungkak Denpasar which lasts from April to September 2018 located at a height of 25 meters above sea level.

\subsection{Materials}

The materials used in this study are Rawita Varieties, Dewata Varieties and Sigantung Varieties, solid rabbit manure, insecticides. While the tools used are scissors, sprayers, meters, stationery, scales, millimeter block paper.

\subsection{Metode Penelitian}

This research is a factorial experiment with a basic randomized blockdesign (RBD) with 2 factors tried. The first factor of the dense rabbit fertilizer dose consists of 4 levels:

$\mathrm{K} 0$ = without fertilizer,

$\mathrm{K} 1$ = rabbit solid fertilizer 10 ton $\mathrm{ha}^{-1}$

$\mathrm{K} 2$ = rabbit solid fertilizer20 ton ha ${ }^{-1}$

K 3 = rabbit solid fertilizer30 ton ha-1

The second factor with 3 levels: 
V 1 = Varieties Rawita

V 2 = Varieties Dewata

V 3 = Varieties Sigantung.

From the experiment, 12 combination treatments will be obtained and will be repeated 3 times so that a total of 36 combination treatments will be taken. The data obtained were analyzed by analysis of variance and continued with the BNT distance test or Duncan $5 \%$.

\subsection{Implementation of Research}

To achieve success in this study, the stages carried out until harvest are as follows:

a. Prepare the nursery media by mixing the soil with manure and cocopit for both small and small amounts of diray and polybag5 : 2,5:1. Insert the media mixture into the tray and small polybag to prepare the seedling nursery.

b. Chili seeds that have been soaked for 2-3 hours are sown in a tray that is placed one seed for one hole. Seeds from different chili varieties are placed in a arranged nursery so that there are no mistakes in planting seeds. If the seeds are 2 weeks old, they are transferred to a small polybag prepared until they are 5 weeks old from the seedlings. During the nursery process, both the tray and the small polybag are always watered in the morning and evening.

c. Soil media that has been sifted will be used as a planting medium for chili seedlings prepared as much as $10 \mathrm{~kg} /$ polybag and 1 day before planting, water is given to the field capacity of each polybag. NPK base fertilizer as much as $1.5 \mathrm{~g} /$ polybag is given at the time of planting. NPK fertilizer will be given back at the age of 30 days after planting in the same amount in all polybags.

d. The soil placed on a large polybag is given solid manure according to treatment $(\mathrm{K} 0=$ without fertilizer, $\mathrm{K} 1=50 \mathrm{~g} /$ polybag fertilizer, $\mathrm{K} 2=100 \mathrm{~g}$ fertilizer $/$ polybag, $\mathrm{K} 3=150$ $\mathrm{g}$ fertilizer / polybag) 7 days before planting and the seedlings are transferred to large polybag by arranging varieties according to treatment. Furadan $3 \mathrm{G}$ needs to be given when planting in order to avoid nematode attacks.

e. Attach a pin to each polybag as soon as the seedlings are transferred to a large polybag.

f. During the process of growth and development, chili will be watered every morning and evening according to soil conditions.

g. Doing prevention of the development of pests and diseases by spraying Demolish and Ditahne M-45 according to plant conditions.

h. Fruit harvest will be carried out in stages with the criteria of the fruit being red and the final harvest according to the time of the study will be counted including green fruit.

i. Variable measurements were observed every 1 week and began to be observed since the plants were 2 weeks after planting.

j. Observations will be made on variables: plant height, branch number, leaf number, leaf area, number of fruit, leaf dry and wet weight, root dry and wet weight, wet and dry weight of fruit, wet and dry weight of stems \& branches.

\section{Results and Discussion}

\subsection{Results}

The results of the statistical analysis on the variables observed in this study and the results of the significance of "Development of Solid Rabbit Cages (K) Against Growth and 
Results of Some Chili (V) Varieties (Capsicum frutescens L.)" and their interactions (K xV) are presented in Table 3.1.

Table 1.Significance of the Development of Solid Rabbit Cages (K) Against the Growth and Results of Some Chili Varieties(V) (Capsicum frutescens L.)"

\begin{tabular}{|c|c|c|c|c|}
\hline \multirow[t]{2}{*}{ No } & \multirow[t]{2}{*}{ Variable } & \multicolumn{3}{|c|}{ Treatment } \\
\hline & & $\begin{array}{c}\text { Rabbit } \\
\text { Fertilizer } \\
\text { Solid } \\
(\mathbf{K}) \\
\end{array}$ & $\begin{array}{c}\begin{array}{c}\text { Variety } \\
\text { Chili }\end{array} \\
(\mathrm{V}) \\
\end{array}$ & Interaction \\
\hline 1. & Maximum Plant Height(cm) & ns & $* *$ & ns \\
\hline 2. & Maximum Branch Number(buah) & $*$ & $* *$ & ns \\
\hline 3. & Maximum Leaves Amount(helai) & $*$ & $* *$ & ns \\
\hline 4. & Maximum Leaf Area $\left(\mathrm{cm}^{2}\right)$ & ns & $* *$ & ns \\
\hline 5. & Number of Harvested Fruits(pcs) & $*$ & $* *$ & ns \\
\hline 6. & Leaves Wet Weight(g) & $*$ & $* *$ & ns \\
\hline 7. & Rod \& Branch Wet Weight(g) & $* *$ & $* *$ & ns \\
\hline 8. & Root Wet Weight(g) & ns & $* *$ & ns \\
\hline 9. & Fruit Weight per Plant(g) & $*$ & $* *$ & ns \\
\hline 10. & Dry Leaf Weight (g) & $*$ & $*$ & ns \\
\hline 11. & Stem \& Branch Dry Weight (g) & $*$ & $* *$ & ns \\
\hline 12. & Dry Root Weight (g) & ns & $* *$ & ns \\
\hline 13. & Dry Fruit Weight (g) & ns & $* *$ & ns \\
\hline
\end{tabular}

Information : $\mathrm{ns}=$ no real effect $(\mathrm{P} \geq 0,05)$

$$
\begin{aligned}
* * & =\text { very real effect }(\mathrm{P}<0,01) \\
* & =\text { have a real impact }(\mathrm{P}<0,05)
\end{aligned}
$$

From Table 3.1. showed an analysis of the variables observed that the interaction between the administration of solid rabbit manure on various small chili varieties $(\mathrm{K} \times \mathrm{V})$ had no significant effect (P50.05).

The treatment of giving solid rabbit manure had no significant effect $(P \geq 0.05)$ on the variables of maximum plant height, maximum leaf area, root wet weight, root dry weight and fruit dry weight but had a significant effect $(\mathrm{P}<0.05)$ on variable number of branches maximum, maximum number of leaves, number of fruits, leaf wet weight, fruit weight, leaf dry weight and stem \& root dry weight and very significant effect $(\mathrm{P}<0.01)$ on stem and branch wet weight variables.

Testing of various varieties had a very significant effect $(\mathrm{P}<0.01)$ on all variables observed except for leaf dry weight significantly $(\mathrm{P}<0.05)$.

Table 2. Average plant height, number of branches, number of leaves, leaf area, number offruits on the treatment of the development of rabbit manure $(\mathrm{K})$ and several varieties chili (V)

\begin{tabular}{|l|c|c|c|c|c|}
\hline Treatment & $\begin{array}{c}\text { Plant } \\
\text { height(cm) }\end{array}$ & $\begin{array}{c}\text { Number of } \\
\text { branches(buah) }\end{array}$ & $\begin{array}{c}\text { Number of } \\
\text { leaves(helai) }\end{array}$ & $\begin{array}{c}\text { Leaf } \\
\text { area }\left(\mathrm{cm}^{2}\right)\end{array}$ & $\begin{array}{c}\text { Number of } \\
\text { fruits(piece) }\end{array}$ \\
\hline Solid Rabbit & & & & & \\
Fertilizer & $137,04 \mathrm{a}$ & $6,22 \mathrm{~b}$ & $244,89 \mathrm{~b}$ & 17012,86 & $70,78 \mathrm{a}$ \\
K0 & $148,40 \mathrm{a}$ & $8,33 \mathrm{a}$ & $275,86 \mathrm{~b}$ & $\mathrm{a}$ & $83,00 \mathrm{a}$ \\
K1 & $147,83 \mathrm{a}$ & $7,67 \mathrm{ab}$ & $299,78 \mathrm{ab}$ & 19894,51 & $86,00 \mathrm{a}$ \\
\hline
\end{tabular}




\begin{tabular}{|c|c|c|c|c|c|}
\hline $\begin{array}{l}\text { K2 } \\
\text { K3 }\end{array}$ & $150,74 \mathrm{a}$ & 9,11 a & $321,11 \mathrm{a}$ & $\begin{array}{c}a \\
20172,45 \\
a \\
23003,12 \\
a\end{array}$ & $108,11 \mathrm{~b}$ \\
\hline BNT 5\% & - & 1,60 & 44,32 & - & 21,50 \\
\hline $\begin{array}{l}\text { Chili Varieties } \\
\text { V1 } \\
\text { V2 } \\
\text { V3 }\end{array}$ & $\begin{array}{l}148,33 \mathrm{~b} \\
125,52 \mathrm{c} \\
164,18 \mathrm{a}\end{array}$ & $\begin{array}{c}7,50 \mathrm{~b} \\
10,92 \mathrm{a} \\
5,08 \mathrm{c}\end{array}$ & $\begin{array}{l}233,83 \mathrm{a} \\
448,17 \mathrm{~b} \\
174,00 \mathrm{c}\end{array}$ & $\begin{array}{c}26697,30 \\
\mathrm{a} \\
13482,84 \\
\mathrm{~b} \\
19882,06 \\
\mathrm{c} \\
\end{array}$ & $\begin{array}{c}50,50 \mathrm{a} \\
176,50 \mathrm{~b} \\
33,92 \mathrm{a}\end{array}$ \\
\hline BNT 5\% & 13,75 & 1,85 & 51,18 & 5331,21 & 24,83 \\
\hline
\end{tabular}

Information: The mean value followed by the same letter in the treatment and column are the same meaning not significantly different from BNT test level 5\%

\section{Plant height (cm)}

The average plant height due to the highest dense rabbit manure at $\mathrm{K} 3$ was 150.74 $\mathrm{cm}$ which was not significantly different from $\mathrm{K} 1, \mathrm{~K} 2$ and $\mathrm{K} 0$, respectively $148.40 \mathrm{~cm}$, $147.83 \mathrm{~cm}$ and $137.04 \mathrm{~cm}$ respectively.

The average maximum plant height in some varieties was shown to be the highest response obtained at V 3, which was $164.18 \mathrm{~cm}$ significantly different from V 1 and $\mathrm{V} 2$ by $148,33 \mathrm{~cm}$ and $125.52 \mathrm{~cm}$, each increasing $10.69 \%$ and $30.80 \%$.

\section{Number of Branches (piece)}

The average maximum number of branches due to the administration of the highest solid rabbit manure at $\mathrm{K} 3$ is 9.11 different significantly with $\mathrm{K} 1, \mathrm{~K} 2$ and $\mathrm{K} 0$ of 8.33 pieces, 7.67 pieces and 6.22 pieces each increasing $9.36 \%, 18.77 \%$ and $46.46 \%$.

The average maximum number of branches in several varieties was shown to be the highest response obtained at V 2 which is 10.92 pieces significantly different from V 1 and V 3 at 7.50 pieces and 5.08 pieces each increasing $45.60 \%$ and $114.96 \%$.

\section{Number of Leaves (strands)}

The average maximum number of leaves due to the highest dense rabbit manure at $\mathrm{K}$ 3 of 321.11 strands differed not significantly with K 2 of 299.78 strands which increased by $7.11 \%$ and were significantly different from K1 and K0 each of 275,86 strands and 244.89 strands where $\mathrm{K} 3$ increased by $16.40 \%$ and $31.12 \%$.

The average maximum number of leaves in several varieties showed the highest response obtained at V 2, namely 448.17 strands significantly different from V 1 and V 3 amounting to 233.83 strands and 174.00 strands increasing $91.66 \%$ and 157.57 respectively. $\%$.

\section{Leaf area $\left(\mathrm{cm}^{2}\right)$}

The average maximum leaf area due to the highest dense rabbit manure at $\mathrm{K} 3$ is $23003.12 \mathrm{~cm} 2$ which is not significantly different from K 2, K 1 and $\mathrm{K} 0$, respectively by $20172.45 \mathrm{~cm} 2,19894.51 \mathrm{~cm} 2,17012,86 \mathrm{~cm} 2$. 
The average maximum leaf area in some varieties was shown to be the highest response obtained at V 1, which was $26697.30 \mathrm{~cm} 2$ significantly different from V 3 and V 2 at $19882.06 \mathrm{~cm} 2$ and $13482.84 \mathrm{~cm} 2$, respectively increasing $34.28 \%$ and $98,01 \%$.

\section{Number of fruits (pieces)}

The average number of fruit harvests due to the highest dense rabbit manure at $\mathrm{K} 3$ of 108.11 was not significantly different with K 2 of 86.00 fruits which increased by $25.71 \%$ and significantly different from K1 and K0 respectively for 83.00 pieces and 70.78 pieces where $\mathrm{K} 3$ increased by $30.25 \%$ and $52.74 \%$.

The average number of fruit harvests in several varieties showed the highest response obtained at V 2, which was 176.50 significantly different from V 1 and V 3 at 50.50 fruits and 33.92 each increasing $249.5 \%$ and $420.34 \%$.

Table 3. Average leaf wet weight, stem \& branch wet weight, root wet weight, weight fruit per plant in the treatment of rabbit $(\mathrm{K})$ and some chili varieties $(\mathrm{V})$

\begin{tabular}{|l|c|c|c|c|}
\hline Treatment & $\begin{array}{c}\text { Leaf wet } \\
\text { weight } \\
(\mathrm{g})\end{array}$ & $\begin{array}{c}\text { Wet stem \& } \\
\text { branch weight } \\
(\mathrm{g})\end{array}$ & $\begin{array}{c}\text { Root wet } \\
\text { weight } \\
(\mathrm{g})\end{array}$ & $\begin{array}{c}\text { Fruit weight } \\
\text { per plant } \\
(\mathrm{g})\end{array}$ \\
\hline Solid & Rabbit & & & \\
Fertilizer & $89,7 \mathrm{a}$ & $150,09 \mathrm{a}$ & $74,83 \mathrm{a}$ & $67,87 \mathrm{a}$ \\
K0 & $105,80 \mathrm{~b}$ & $186,15 \mathrm{~b}$ & $97,01 \mathrm{a}$ & $80,22 \mathrm{ab}$ \\
K1 & $108,07 \mathrm{~b}$ & $196,83 \mathrm{bc}$ & $98,51 \mathrm{a}$ & $95,48 \mathrm{bc}$ \\
K2 & $112,02 \mathrm{~b}$ & $224,12 \mathrm{c}$ & $107,12 \mathrm{a}$ & $107,10 \mathrm{c}$ \\
K3 & & & & \\
\hline BNT 5\% & 13,62 & 33,93 & - & 24,40 \\
\hline Chili Varieties & & & & \\
V1 & $127,33 \mathrm{a}$ & $234,43 \mathrm{a}$ & $105,14 \mathrm{a}$ & $60,46 \mathrm{a}$ \\
V2 & $77,68 \mathrm{c}$ & $136,19 \mathrm{~b}$ & $51,10 \mathrm{~b}$ & $129,27 \mathrm{~b}$ \\
V3 & $106,74 \mathrm{~b}$ & $197,28 \mathrm{a}$ & $126,87 \mathrm{a}$ & $73,28 \mathrm{a}$ \\
\hline BNT 5\% & 15,73 & 39,18 & 28,56 & 28,18 \\
\hline
\end{tabular}

Keterangan : The mean value followed by the same letter in the treatment and column are the same meaning not significantly different from BNT test level 5\%

\section{Leaves Wet Weight (g)}

The average wet weight of leaves due to the highest dense rabbit manure at $\mathrm{K} 3$ of $112.02 \mathrm{~g}$ was not significantly different from K 2 and $\mathrm{K} 1$ of $108.67 \mathrm{~g}$ and $105.80 \mathrm{~g}$ which increased by $3.08 \%$ and $5.87 \%$ and significantly different from K0 of $89.77 \mathrm{~g}$ where K3 increased by $24.79 \%$.

The average wet weight of leaves in several varieties showed the highest response obtained at V 1, ie $127.33 \mathrm{~g}$ significantly different from V 2, $106.74 \mathrm{~g}$, increasing $19.29 \%$ and V1 against V3 which was $77.68 \mathrm{~g}$, increasing by $63.92 \%$. Likewise, V3 was significantly different from V2 and V3 which increased $37.41 \%$.

\section{Rod and Branch Wet Weight (g)}

The average stem and branch wet weight due to the highest dense rabbit manure at $\mathrm{K} 3$, $224.12 \mathrm{~g}$, was not significantly different from K 2 ie and K3 increased by $13.86 \%$. K3 was 
significantly different from K1 and K0, which were $186.15 \mathrm{~g}$ and $150.09 \mathrm{~g}$, but still experienced increases of $20.40 \%$ and $49.32 \%$ respectively.

The average stem and branch wet weight in several varieties showed the highest response obtained at V 1 which was $234.43 \mathrm{~g}$ which was not significantly different from V 3 which was $197.28 \mathrm{~g}$, increasing by $18.83 \%$ and V1 against V2 which was $136.19 \mathrm{~g}$ increasing by $72.13 \%$.

\section{Root Wet Weight (g)}

The average wet weight of leaves due to the highest dense rabbit manure given at $\mathrm{K} 3$, $107.12 \mathrm{~g}$, was not significantly different from K 2, K 1 and K 0 which were $98.51 \mathrm{~g}, 97.01 \mathrm{~g}$ and $78.83 \mathrm{~g}$ but still increased respectively $8.74 \%, 10.42 \%$ and $35.89 \%$.

The average wet weight of leaves in several varieties showed the highest response obtained at V 3, $126.87 \mathrm{~g}$, which was not significantly different from V 1, which was 105.14 $\mathrm{g}$, increasing by $20.68 \%$ and V1 significantly different from V2 which was $51.10 \mathrm{~g}$ increasing by $148.28 \%$.

\section{Fruit Weight Per Plant(g)}

The average fruit weight due to the highest dense rabbit manure at $\mathrm{K} 3$ of $107.10 \mathrm{~g}$ was not significantly different from K 2 and $\mathrm{K} 1$ of $95.48 \mathrm{~g}$ and $80.22 \mathrm{~g}$ which increased $12.17 \%$ and $33.51 \%$ and significantly different from $\mathrm{K} 0$ which is $67.87 \mathrm{~g}$ where $\mathrm{K} 3$ increased by $57.80 \%$.

The average fruit weight in several varieties showed the highest response obtained at $\mathrm{V}$ 2, namely $129.27 \mathrm{~g}$, significantly different from V 3 and V 2, namely $73.28 \mathrm{~g}$ and $60.46 \mathrm{~g}$ each increasing $76.41 \%$ and $113.81 \%$.

Table 4. Average oven dry weight of leaves, oven dry stems \& branches, dry weight oven root, fruit oven dry weight per plant in the development treatment rabbit manure $(\mathrm{K})$ and some chili varieties $(\mathrm{V})$

\begin{tabular}{|l|c|c|c|c|}
\hline Treatment & $\begin{array}{c}\text { Dry leaf oven } \\
\text { weight }(\mathrm{g})\end{array}$ & $\begin{array}{c}\text { Dry oven \& branch } \\
\text { weight }(\mathrm{g})\end{array}$ & $\begin{array}{c}\text { Dry oven root } \\
\text { weight }(\mathrm{g})\end{array}$ & $\begin{array}{c}\text { Fruit oven dry } \\
\text { weight }(\mathrm{g})\end{array}$ \\
\hline Solid Rabbit Fertilizer & $15,67 \mathrm{a}$ & $27,74 \mathrm{a}$ & $65,32 \mathrm{a}$ & $13,11 \mathrm{a}$ \\
K0 & $17,27 \mathrm{ab}$ & $36,52 \mathrm{a}$ & $82,54 \mathrm{a}$ & $17,23 \mathrm{ab}$ \\
K1 & $20,45 \mathrm{c}$ & $32,61 \mathrm{a}$ & $81,08 \mathrm{a}$ & $18,46 \mathrm{~b}$ \\
K2 & $19,64 \mathrm{bc}$ & $50,75 \mathrm{~b}$ & $88,45 \mathrm{a}$ & $20,94 \mathrm{~b}$ \\
K3 & 3,11 & 11,40 & - & - \\
\hline BNT 5\% & $20,91 \mathrm{a}$ & $50,01 \mathrm{a}$ & $91,36 \mathrm{a}$ & $10,84 \mathrm{a}$ \\
\hline Chili Varieties & $16,82 \mathrm{~b}$ & $27,95 \mathrm{~b}$ & $40,43 \mathrm{~b}$ & $29,91 \mathrm{~b}$ \\
V1 & $17,04 \mathrm{~b}$ & $32,75 \mathrm{~b}$ & $106,26 \mathrm{a}$ & $11,56 \mathrm{a}$ \\
V2 & 3,59 & 13,17 & 30,56 & 5,69 \\
V3 & & & & \\
\hline BNT 5\% & & & & \\
\hline
\end{tabular}

Keterangan : Nilai rata-rata yang diikuti oleh huruf yang sama pada perlakuan dankolom yang sama berarti berbeda tidak nyata pada taraf uji BNT 5\%

\section{Dry leaf oven weight (g)}

The average leaf oven dry weight due to giving rabbit manure to the highest at $\mathrm{K} 2$ at $20.45 \mathrm{~g}$ was not significantly different with K 3 at $19.64 \mathrm{~g}$ increasing by $4.12 \%$ and $\mathrm{K} 2$ significantly different from $\mathrm{K} 1$ and $\mathrm{K} 0$ which was $17.27 \mathrm{~g}$ and 15.67 have increased by $18.41 \%$ and $30.50 \%$. 
The average oven dry weight of leaves in several varieties showed the highest response obtained at V 1 which is $20.91 \mathrm{~g}$ significantly different from V 3 and V 2 which is $17.04 \mathrm{~g}$ and $16.82 \mathrm{~g}$ each increased by $22.71 \%$ and $24,32 \%$.

\section{Heavy Dry Oven Stems and Branches(g)}

The average stem and branch oven dry weight due to the highest dense rabbit manure at $\mathrm{K} 3$ of $50.75 \mathrm{~g}$ was significantly different from K 1, K2 and K0, which was $36.52 \mathrm{~g}, 32.61 \mathrm{~g}$ and 27.74 increased by $38.96 \%, 55.63 \%$ and $82.95 \%$.

The average stem and branch oven dry weight in several varieties showed the highest response obtained at $\mathrm{V} 1$ which was $50.01 \mathrm{~g}$ significantly different from V 3 and V 2 which was $32.75 \mathrm{~g}$ and $27.95 \mathrm{~g}$ each increasing $52.70 \%$ and $78.93 \%$.

\section{Heavy Dry Root Oven(g)}

The average dry oven root weight due to the highest dense rabbit manure at $\mathrm{K} 3$ was $88.45 \mathrm{~g}$ which was not significantly different from $\mathrm{K} 1, \mathrm{~K} 2$ and $\mathrm{K} 0$, respectively $82.54 \mathrm{~g}$, $81.08 \mathrm{~g}$ and $65,32 \mathrm{~g}$.

The average root oven dry weight in some varieties indicated the highest response obtained at V 3, $106.26 \mathrm{~g}$, which was not significantly different from V 1 which was $91.36 \mathrm{~g}$ where V 3 increased by $16.31 \%$ and was significantly different from V 2 which $40.43 \mathrm{~g}$ increased by $162.82 \%$.

\section{Heavy Dry Fruit Oven(g)}

The average dry fruit oven weight due to the highest dense rabbit manure at $\mathrm{K} 3$ is 20.94 $\mathrm{g}$ which is not significantly different from $\mathrm{K} 1$ and $\mathrm{K} 2$ by $18.46 \mathrm{~g}$ and $17.23 \mathrm{~g}$, respectively. The lowest value obtained at $\mathrm{K} 0$ is equal to $13.11 \mathrm{~g}$ different from K 3 and increases $59.73 \%$.

The average fruit oven dry weight in several varieties indicated the highest response obtained at V 2, which is $29.91 \mathrm{~g}$ significantly different from V 3 and V 1 which is $11.56 \mathrm{~g}$ and $10.84 \mathrm{~g}$ increased by $158.74 \%$ and $175.92 \mathrm{~g} \%$.

\subsection{Discussion}

From the analysis of the variables observed it was found that the interaction between the administration of solid rabbit manure on various small chili varieties $(\mathrm{K} \mathrm{x} V$ ) had no significant effect $(\mathrm{P} \geq 0.05)$. The fruit weight per plant in the highest dense rabbit fertilizer at $\mathrm{K}$ 3 was $107.10 \mathrm{~g}$ which was not significantly different from K2 and $\mathrm{K} 1$ at $95.48 \mathrm{~g}$ and $80.22 \mathrm{~g}$ which increased $12.17 \%$ and $33.51 \%$ and significantly different with $\mathrm{K} 0$ which is $67.87 \mathrm{~g}$ where K3 increased by $57.80 \%$. Hardjowigeno [2] states that to improve soil fertility is to fertilize with organic fertilizer or manure. Nutrient content in manure is not too high, but this type of fertilizer has other features that can provide physical properties of the soil such as soil permiability, soil porosity, soil structure, power to resist water and soil cations and so on. Solid rabbit manure in the soil has a good influence on the physical properties of the soil, this causes better root growth so that it makes it easier for plant roots to absorb nutrients in dense rabbit manure. The results of this study showed that the high fruit weight in the administration of solid rabbit fertilizer at the K3 dose of 30 tons ha- 1 was supported by the highest plant height obtained in $\mathrm{K} 3$ of $150.74 \mathrm{~cm}$, the highest number of branches was 9.11 fruits, the highest number of leaves was 321, 11 strands, the broadest leaf area of $23,003.12 \mathrm{~cm} 2$, the highest number of fruits amounted to 108,11 fruit, the heaviest weight of leaf weight was $112.02 \mathrm{~g}$, the heaviest weight of stem and branches was $224.12 \mathrm{~g}$, the heaviest weight of roots was $107.12 \mathrm{~g}$. The existence of a high response by all observed variables is supported by the 
opinion of Rinsema [3] that the role of nutrients is to help stimulate the development of all parts of the plant so that the plants will grow faster, the absorption of nutrients is relatively large. Furthermore, Lakitan [4] states that the success and response of plants to fertilizer application is largely determined by several factors including plant physiological properties, technical culture actions and plant morphology. The role of manure by Sarief [5] stated that manure is an organic material and humus which has an influence on physical changes, the biological chemistry of the soil which contains macro and micro nutrients, so that more nutrients are available for plants. According to Setyamidjadja [6] the function of manure on agricultural land is to increase the content of organic matter (humus), increase soil fertility by increasing plant nutrients, improve the life of soil microorganisms, and protect the soil against damage caused by erosion. Lakitan [7]states that organic fertilizer is not easily washed and available to plants after the organic material has been decomposed by soil microorganisms and is available for a long time. The very low element content of $\mathrm{N}, \mathrm{P}, \mathrm{K}$ and $\mathrm{C}$ organic on the soil used as a medium gives a very high response to all observed variables so that very positive support for fruit weight per plant at a dose of 30 tons ha-1. Sajimin et al. [8] found that the use of rabbit manure on potato and cabbage plants increased production by an average of $23.5 \%$ compared to sheep fertilizer. Ruminta et al [9] found that 5 tons / ha rabbit manure treated the best independent effect on panicle length, panicle weight per clump and seed weight per plant.

The fruit weight in the treatment of some of the highest response varieties was obtained at V2 (Rawita), which was $129.27 \mathrm{~g}$, significantly different from V3 (Sigantung) and V1 (Dewata) which were $73.28 \mathrm{~g}$ and $60.46 \mathrm{~g}$ each increasing $76.41 \%$ and $113.81 \%$. The highest fruit weight in V2 is supported by the highest number of branches of 10.92, the highest number of leaves is 448.17 pieces, the highest number of fruits is 176.50 pieces. The increasing number of branches will cause more leaves, and the greater the contribution of photosynthesis results will be able to contribute to the increase in the number of flowers formed and the greater the chance to get the most fruit. Syukur et al (2016) [10] stated that to increase the productivity of chili, the use of superior quality seeds is absolutely necessary. Furthermore, it is stated that the more chili varieties on the market, the selection must be released by the Minister of Agriculture to be used for chili cultivation. The superior character of chili varieties should meet several criteria including high productivity, early harvest age, resistance to pest and disease attacks, longer shelf life, certain spiciness levels and fruit quality in accordance with consumer tastes.

\section{Conclusion}

The results of the study can be concluded, including:

1. The interaction between the development of solid rabbit manure $(\mathrm{K})$ on the growth and yield of several chili (V) (Capsicum frutescens L.) varieties had no significant effect $(\mathrm{P} \geq 0.05)$.

2. Solid Rabbit Cage $(\mathrm{K})$ had a significant effect $(\mathrm{P}<0.05)$ on the weight of harvested fruit per plant. The fruit weight per plant in the highest dense rabbit fertilizer at $\mathrm{K} 3$ was $107.10 \mathrm{~g}$ which was not significantly different from $\mathrm{K} 2$ and $\mathrm{K} 1$ at $95.48 \mathrm{~g}$ and $80.22 \mathrm{~g}$ which increased $12.17 \%$ and $33.51 \%$ and significantly different with $\mathrm{K} 0$ which is $67.87 \mathrm{~g}$ where K3 increased by $57.80 \%$

3. Chili (V) varieties tested had a very significant effect $(\mathrm{P}<0.01)$ on harvested fruit weight per plant. The fruit weight in the treatment of some of the highest response varieties was 
obtained at V 2 (Rawita), namely $129.27 \mathrm{~g}$, significantly different from V3 (Sigantung) and V1 (Dewata), namely $73.28 \mathrm{~g}$ and $60.46 \mathrm{~g}$ each increasing $76.41 \%$ and $113.81 \%$.

\section{References}

[1] A. A. N.; M. Y.; L. K. Mayun Wirajaya, "Pemberian BeberapaJenis Pupuk Kandang danPemangkasan Bagian Apikal Terhadap Pertumbuhan Dan Hasil Tanaman Cabai (Capsicum frutescens L.). Tesis. Agroteknologi Fak.Pertanian Universitas Warmadewa Denpasar,” 2017.

[2] S. Hardjowigeno, Ilmu Tanah. Jakarta: PT.Mediyatama Sarana Perkasa, 1987.

[3] Rinsema, Pupuk dan Cara Pemupukan. Jakarta: Bharata, 1993.

[4] B. Lakitan, Dasar-Dasar Fisiologi Tanaman. Jakarta: PT. Raja Grafindo Persada, 2004.

[5] S. Sarief, Kesuburan dan Pemupukan Tanah Pertanian. Bandung: Penerbit Pustaka Buana, 1989.

[6] D. M. E. Setyamidjaja, Pupuk dan Pemupukan. Jakarta: CV.Simplex, 1986.

[7] B. Lakitan, Hortikultura; Teori, Budidaya dan Pasca Panen. Jakarta: PT. Raja Grafindo Persada, 1995.

[8] N. D. P. Sajimin , Yono C.Rahardjo, Potensi Kotoran Kelinci Sebagai Pupuk Organik dan Pemanfaatannya Pada Tanaman Pakan dan Sayuran. Lokakarya Nasional Potensi dan Peluang Pengembangan Usaha Agribisnis Kelinci. Bogor: Balai Penelitian Ternak, 2005.

[9] M. L. H. Ruminta, A.Wahyudin, "Pengaruh Pupuk N,P,K dan Pupuk Organik Kelinci Terhadap Hasil Sorgum (Sorghum bicolor [Linn] Moench) di Lahan Tadah Hujan Jatinangor,” J. Kultiv., vol. 16, no. 2, 2017.

[10] M. ;Rahmi Y.;Rahmansyah D. Syukur, Budidaya Cabai ; Panen Setiap Hari. Jakarta Timur: Penebar Swadaya, 2016. 